\title{
Severe bone and mineral disease in an adolescent with chronic kidney disease: a case from the 70 s?
}

\author{
Catarina Gomes, ${ }^{1}$ Filipa Mestre A Dias, ${ }^{2}$ Liliana Franco, $^{3}$ Margarida Almeida ${ }^{1}$
}

${ }^{1}$ Department of Pediatrics, Hospital de Santa MariaCHLN, Lisboa, Portugal ${ }^{2}$ Department of Pediatrics, Centro Hospitalar do Algarve —Unidade de Faro, Faro, Portugal

${ }^{3}$ Department of Pediatrics, Hospital São Francisco Xavier, Lisboa, Portugal

\section{Correspondence to} Dr Catarina Gomes, catarina.j.gomes@gmail.com

Accepted 23 September 2015
CrossMark

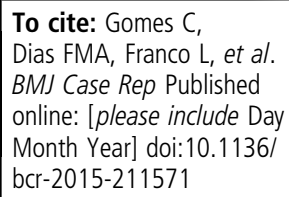

\section{DESCRIPTION}

There is currently great focus on prevention of mineral and bone disorder from early stages of chronic kidney disease (CKD) in children. ${ }^{1}$ Nowadays, the extreme complications of bone disorder in end-stage CKD are rarely seen in developed countries. However, access to medical resources in developing countries is difficult, and severe CKD bone and mineral disorder is still common.

A 13-year-old girl was transferred from Angola due to end-stage CKD. She was undergoing haemodialysis from the age of 9 years, 3 years after the diagnosis of CKD of undetermined aetiology. Her mother reported progressive bone deformities in the child and an increase in head circumference during the previous year. At physical observation, a head/body disproportion with macrocrania was noted (figure 1); the patient weighed $22 \mathrm{~kg}$ $(\mathrm{SD}=5.33)$, had a height of $130 \mathrm{~cm}(\mathrm{SD}=3.9)$ and head circumference of $59.5 \mathrm{~cm}$ (>p98). Ancillary testing revealed serum calcium $2.65 \mathrm{mmol} / \mathrm{L}$, ionised calcium $1.24 \mathrm{mmol} / \mathrm{L}$, phosphorus $1.52 \mathrm{mmol} / \mathrm{L}$, parathyroid hormone $323.3 \mathrm{pmol} / \mathrm{L}$ $(3047 \mathrm{pg} / \mathrm{mL})$ and 25-hydroxy vitamin D $49.7 \mathrm{nmol} / \mathrm{L}$. Skull radiography and head CT scan revealed a diploic enlargement of skull and face bones (figure 2), and the patient was diagnosed with uraemic leontiasis ossea. During follow-up, she had continuing bone and mineral disease that was difficult to control, with persistent high levels of parathormone (72.3-1006.9 pmol/L), despite therapeutic adjustments with increasing doses of vitamin D analogues.

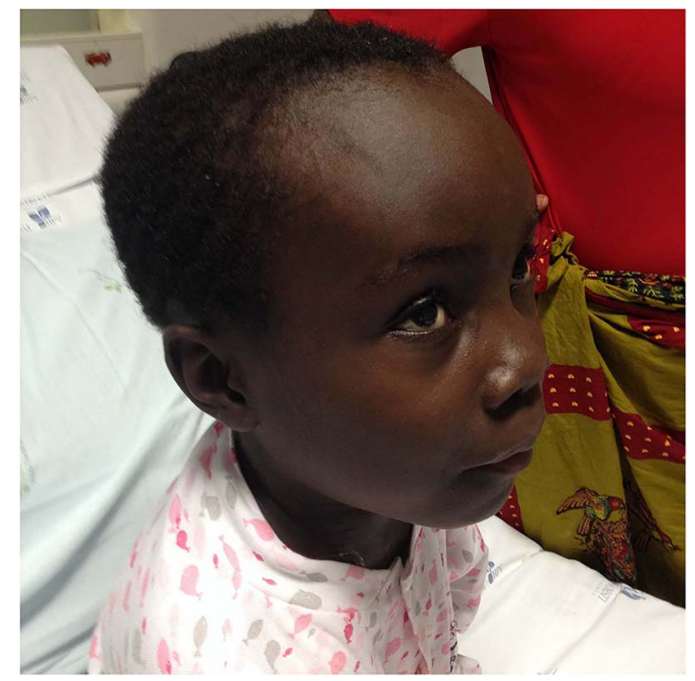

Figure 1 Macrocrania and enlarged facial bonesleontiasis ossea.

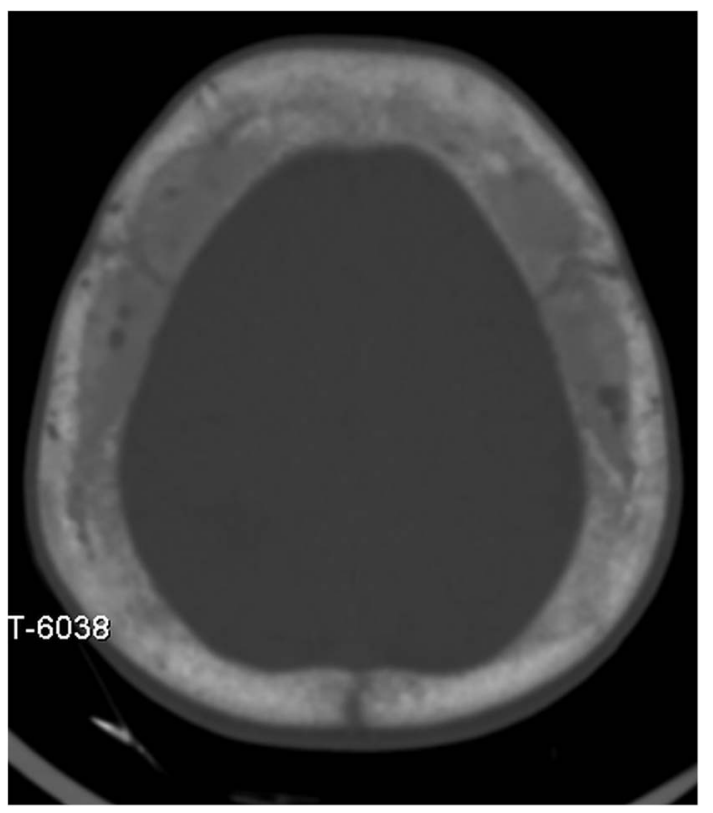

Figure 2 Cranial tomography scan with diploic enlargement and mineralisation changes of cranial bones.

Uraemic leontiasis ossea is an inflammatory hyperostotic bone disease, localised to the cranial and maxillary bones. ${ }^{2}{ }^{3}$ This entity is a rare manifestation of CKD and seldom seen in children, especially in developed countries. Management of refractory secondary hyperparathyroidism is not clear and could include a trial of off-label treatment with cinacalcet, before considering parathyroidectomy.

\section{Learning points}

- Uraemic leontiasis ossea is a rare entity but should be kept in mind in children with head enlargement and long-term chronic kidney disease (CKD).

- Phosphorus, calcium, parathyroid hormone and vitamin $D$ control is essential from early stages of CKD in order to prevent bone deformities.

Acknowledgements The authors would like to acknowledge Dr Rosário Stone.

Competing interests None declared.

Patient consent Obtained.

Provenance and peer review Not commissioned; externally peer reviewed. 


\section{REFERENCES}

1 Kidney Disease: Improving Global Outcomes (KDIGO) CKD Work Group. KDIGO 2012 Clinical Practice Guideline for the evaluation and management of chronic kidney disease. Kidney Int Supp/ 2013;3:1
2 Kumar S, Thuraisingham R, Yaqoob M. Big-head disease: uremic leontiasis ossea. Kidney Int 2006;69:1709.

3 Haroyan H, Bos A, Ginat DT. Uremic leontiasis ossea. Am J Otolaryngol 2015:36:74-6.

Copyright 2015 BMJ Publishing Group. All rights reserved. For permission to reuse any of this content visit http://group.bmj.com/group/rights-licensing/permissions.

BMJ Case Report Fellows may re-use this article for personal use and teaching without any further permission.

Become a Fellow of BMJ Case Reports today and you can:

- Submit as many cases as you like

- Enjoy fast sympathetic peer review and rapid publication of accepted articles

- Access all the published articles

- Re-use any of the published material for personal use and teaching without further permission

For information on Institutional Fellowships contact consortiasales@bmjgroup.com

Visit casereports.bmj.com for more articles like this and to become a Fellow 